\title{
Training Penulisan Systematic Literature Review dengan Nvivo 12 Plus
}

\author{
Hafidhah $^{1^{*}}$, Aprilya Dwi Yandari ${ }^{2}$ \\ 1, 2, Fakultas Ekonomi dan Bisnis, Universitas Wiraraja \\ ${ }^{1}$ hafidhah@wiraraja.ac.id, ${ }^{2}$ aprilya@wiraraja.ac.id
}

\begin{abstract}
Abstrak
Penulisan literature review merupakan salah satu tahapan penting yang harus dibuat oleh seorang peneliti baik dosen maupun mahasiswa yang sedang tugas akhir. Saat ini kebanyakan peneliti menggunakan pendekatan tradisional dalam penulisan literature review. Hal ini memiliki kelemahan yaitu dari segi efektivitas dan efisiensi. Seorang peneliti harus mengumpulkan banyak jurnal ilmiah dan memahami isinya sebelum menulisnya. Hal ini tentunya kurang efektif karena akan memakan banyak waktu. Melihat permasalahan tersebut, Nvivo dipandang sebagai solusi untuk mengatasi hal demikian. Program PKM ini bertujuan untuk memudahkan peserta dalam penyusunan literature review. Kegiatannya dirancang sedemikian rupa sehingga peserta akan mudah memahami langkah-langkah penyusunan literature review dengan Nvivo. Dilaksanakannya PKM ini menjadikan peserta memahami bagaimana cara import dokumen berupa artikel dari Mendeley atau Endnote ke dalam Nvivo, melakukan coding, menganalisis, dan menampilkan hasil analisis artikel Nvivo, dan kemudian menuliskannya dalam sebuah literature review yang sistematis. Nvivo memungkinkan peserta untuk mengeksplorasi sejumlah besar dokumen tekstual untuk melihat pola dan instrumen penelitian yang digunakan.
\end{abstract}

Kata Kunci: systematic, literature review, Nvivo

\section{Pendahuluan}

Seni dan perkembangan sains bertanggung jawab dalam menciptakan pelestarian dan perkembangan pengetahuan umat manusia. Meskipun ada perbedaan cara dan pola membaca dan menulis di antara orang-orang, terutama akademisi di seluruh dunia, semuanya bertujuan untuk memberikan kontribusi yang signifikan terhadap perkembangan umat manusia dan kemajuan pengetahuan di semua bidang kehidupan. Secara khusus, pendidikan dan penelitian telah sangat diuntungkan dari perkembangan seni dan ilmu penulisan karena karya yang dilakukan dan atau dicapai dilestarikan dalam bentuk tulisan dan bentuk lainnya.

Disadari atau tidak, tujuan dari setiap penelitian adalah untuk mengungkap kebenaran (MacDonald, 2014) sehingga pembahasan masalah tinjauan literatur bukanlah hal baru dalam penelitian. Tinjauan dan penulisan literatur adalah aspek yang tak terpisahkan dari setiap penelitian akademik dan semakin mendapatkan tempat sebagai sebuah kajian dan bidang penelitian. Hal ini terutama terjadi, karena standar yang ditetapkan selalu ditingkatkan, sehingga pengulas sebuah literatur dan penulis harus memberikan metode yang tepat untuk diikuti dalam pencarian bahan untuk penilaian, evaluasi, dan atau 
replika metode yang digunakan di masa depan. Penulisan dan publikasi akademis adalah tugas yang menantang dan seringkali membutuhkan banyak waktu dan energi sehingga, banyak akademisi dan peneliti tidak suka mengulas/menulis secara akademis karena beberapa faktor seperti: perasaan tidak fokus saat memulai pekerjaan atau tersendat di beberapa titik saat menulis, kegugupan, dan rasa minder di hadapan penulis lain (Adams et al., 2017). Tetapi bagaimanapun juga, menulis memiliki arti yang sangat penting bagi perkembangan ilmu pengetahuan. Demikian juga, tinjauan dan penulisan literatur yang efektif dan efisien adalah tugas besar yang menuntut banyak keterlibatan yang berkaitan dengan pencarian bahan dari berbagai sumber, dengan hati-hati, memilih yang relevan, dan mendapatkan informasi atau data yang diperlukan secara khusus, pemikiran kritis tentang literatur, merangkum bagian-bagian yang relevan, dan kemudian membuat kutipan yang tepat yang dengan sistematis.

Tinjauan literatur adalah fitur umum dari semua produk penelitian, terlepas dari disiplin atau subjeknya. Sebuah tinjauan literatur menjadi dasar untuk semua jenis penelitian atau pekerjaan yang dipelajari. Namun, terkadang proses tinjauan tersebut biasanya diabaikan sebagai bentuk analisis kualitatif. Proses yang dilakukan dalam membangun argumen dari sebuah literatur mirip dengan proses yang terlibat dalam menganalisis data kualitatif. Proses tersebut meliputi: membaca dan merefleksikan, berinteraksi dengan literatur/data dan mengomentarinya, mengidentifikasi tema kunci dan melakukan pengkodean; mengekstrak dari kutipan untuk digunakan saat menulis; menghubungkan ide-ide serupa dari berbagai artikel, mengidentifikasi kontradiksi dalam argumen, membandingkan perbedaan dalam artikel, membangun argumen/analisis sendiri dengan tautan ke bukti pendukung dalam data/literatur (Pautasso, 2013).

Para peneliti telah mengembangkan berbagai strategi untuk menangani jumlah bahan yang dihasilkan oleh tinjauan literatur. Di masa lalu, sistem indeks digunakan sebagai alat tetapi dalam beberapa tahun terakhir, perangkat lunak bibliografi telah muncul sebagai alat yang disukai untuk mengatur dan membuat sebuah literatur review. Paket seperti EndNote, Reference manager, Mendeley, dll. Penggunaan alat dalam dalam mengolah sebuah referensi tentunya sangatlah membantu. Hal ini memungkinkan untuk mengunduh abstrak dalam beberapa atau seluruh artikel untuk dimasukkan dalam basis data bibliografi. Perangkat lunak tersebut menawarkan cara yang fleksibel untuk mencari dan mengurutkan referensi (Machi \& McEvoy, 2008). Mereka memiliki tautan langsung dengan paket pengolah kata, membuatnya mudah untuk memasukkan kutipan yang benar pada suatu titik dalam teks. Mereka juga memiliki kemampuan untuk menghasilkan bibliografi dalam gaya yang sesuai untuk berbagai jurnal. Selain itu, dimungkinkan pula untuk berkomentar dan merenungkan sebuah artikel, mengkodekannya dengan kata-kata kunci tertentu dll. Namun, paket-paket ini tidak dirancang untuk analisis data, sehingga proses ini dapat dilakukan hanya dengan cara yang terbatas. Paket analisis perangkat lunak khusus diperlukan untuk mendukung proses analisis yang terlibat dalam tinjauan literatur.

Paket perangkat lunak seperti Atlas.ti, N4 Classic, N5, NVivo, WinMax dll. Dapat digunakan untuk mendukung proses analisis yang terlibat dalam tinjauan literatur (Edwards-Jones, 2014). Mereka tidak mengganti perangkat lunak bibliografi yang disebutkan di atas, karena mereka tidak memiliki alat bibliografi yang dimiliki paketpaket tersebut. Tetapi alat analitis mereka dapat digunakan sebagai tambahan alat 
bibliografi untuk mendukung seluruh proses tinjauan literatur. Dari semua paket perangkat lunak analisis kualitatif, hanya NVivo (sampai saat ini) memiliki seperangkat alat tertentu yang ideal untuk menganalisis literatur. Dimungkinkan untuk menganalisis literatur dalam paket lain yang disebutkan, tetapi alat-alat tersebut tidak sefleksibel NVivo untuk tujuan ini.

Tinjauan dan penulisan literatur adalah bagian yang tak terpisahkan dari setiap pekerjaan penelitian. Namun, proses melaksanakannya secara teoritis dan praktis telah membingungkan, membosankan, dan memakan waktu, energi dan sumber daya, terutama untuk peneliti yang tidak berpengalaman dan memiliki waktu singkat dalam menyusunnya. Oleh karena itu, banyak peneliti, dan penulis literatur, akhirnya menulis ulang cerita, tidak fokus pada subjek yang menjadi perhatian mereka, dan entah menulis ulang apa yang telah dilakukan orang lain, atau membuatnya menjadi sampah di dalam dan di luar karya orang lain.

Tinjauan pustaka dan penulisan literatur menjadi dasar dari setiap penelitian dan penulisan akademis, dan hal itu merupakan tahapan penting dan sangat diperlukan untuk setiap pekerjaan penelitian akademik. Namun, proses penulisan sebuah tinjauan pustaka yang sistematis telah menjadi permasalahan kompleks, dan membosankan, terutama bagi para peneliti pemula dan mahasiswa yang belum atau tidak berpengalaman. Kesulitan dalam memahami, mengkaji, dan menulis literatur terutama berasal dari kegagalan sejak awal untuk secara jelas mengidentifikasi apa yang diinginkan oleh pengulas dan bagaimana cara mencarinya dengan cara yang sistematis dan komprehensif. Meninjau dan menulis literatur akademik adalah tugas yang sangat besar, untuk itu seorang peneliti harus fokus pada tujuan spesifik serta penyediaan referensi yang memadai dan relevan. Dengan pemahaman yang tepat, penulisan sebuah literatur review dapat dikuasai dan dilakukan dengan mudah. Kegiatan PkM ini sangat penting bagi akademisi dan mahasiswa yang sedang menjalani proses penyelesaian tugas akhir dalam pembuatan tinjauan pustaka.

Pentingnya kegiatan ini karena saat ini proses penyusunan sebuah tinjauan pustaka oleh mahasiswa dan akademisi dilakukan seadanya. Mereka belum memahami bagaimana penyusunan literatur review yang baik. Prosesnya dilakukan seadanya dengan literatur/data yang minim sehingga literatur review yang dibuatnya tidaklah menggambarkan isu yang dingkat dalam penelitian. Proses penyusunan literatur review ini akan dipermudah dengan menggunakan sebuah paket aplikasi Nvivo12 plus yang memiliki fitur-fitur yang mampu membantu akademisi dan mahasiswa dalam penulisan literature review yang mudah, efektif, dan efisien. Tanpa pelatihan, tinjauan literatur dapat dilakukan dengan buruk. Kesalahan umum adalah kecenderungan untuk hanya menceritakan kembali penelitian menggunakan kutipan untuk menunjukkan pemahaman, menghasilkan ulasan terputus-putus yang tidak memiliki garis argumen yang kuat.

\section{Metode Pelaksanaan}

Bagian ini menjelaskan metode yang akan digunakan dalam pelaksanaan PkM. Untuk memaksimalkan hasil dan meningkatkan pemahaman peserta, maka dilakukan beberapa tahapan diantara yaitu : Pertama Persiapan. Langkah ini meliputi proses instalasi NVivo pada masing-masing laptop peserta, Mencari referensi melalui NCapture yang telah 
diintegrasikan dengan google chrome, dan Mengurutkan referensi serta mempersiapkan proses impor ke Nvivo. Kedua, Analisis Langkah ini meliputi proses pengklasifikasian referensi, pada aplikasi NVivo, Visualisasi, dan proses deskriptif awal terhadap topik serta pengkodean referensi untuk dijadikan menemukan sebuah tema. Ketiga, menulis tinjauan pustaka. Langkah ini meliputi proses meringkan dan menyimpulkan data dari NVivo, dan selanjutnya adalah menulis tinjauan pustaka.

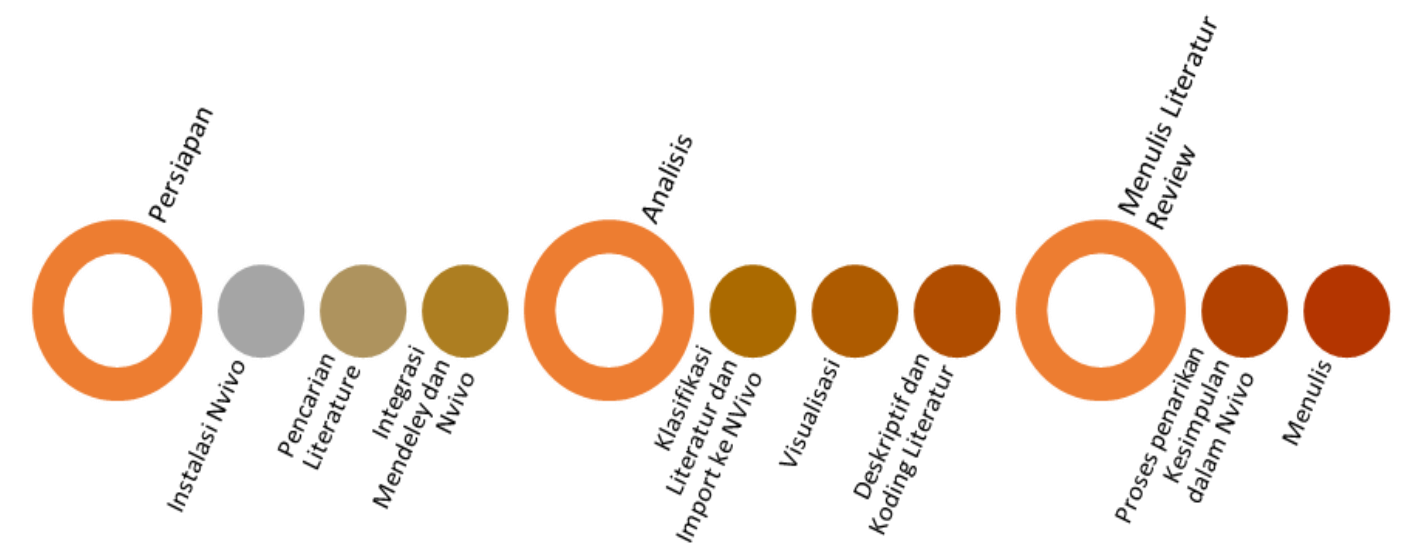

Gambar 1. Tahapan Kegiatan PKM

Kegiatan PkM dilaksanakan di ruang kelas Fakultas Ekonomi dan Bisnis Universitas Wiraraja. Kegiatan ini dilaksanakan selama empat kali pertemuan dengan melibatkan dosen dan mahasiswa Fakultas Ekonomi dan Bisnis Universitas Wiraraja. Pada pertemuan pertama dilaksanakan pada hari selasa tanggal o7 September 2020 dilakukan persiapan berupa instalasi perangkat lunak Nvivo pada masing-masing laptop peserta serta melakukan proses integrasi Mendeley dan Nvivo12 plus. Pada kesempatan ini pula kami memberikan pelatihan tentang pencarian literatur yang efektif menggunakan metode Boolean. Kegiatan selanjutnya meliputi proses analisis dan menulis literature review dengan bantuan Nvivo 12 plus.

Selanjutnya proses terakhir adalah evaluasi terhadap keberhasilan kegiatan PkM. Proses evaluasi dilakukan dengan diskusi dengan peserta tentang permasalahan yang dihadapi serta peningkatan kemampuan dalam penulisan literature review. Evaluasi juga dilakukan melalui angket untuk melihat respon peserta atas pelaksanaan kegiatan PkM.

\section{Hasil dan Pembahasan}

Tujuan utama kegiatan PkM ini adalah untuk memberikan pelatihan kepada para peserta yang merupakan dosen dan mahasiswa dengan memberikan pedoman setiap tahapan dan proses penyusunan tinjauan literatur dengan menggunakan Nvivo. Sebelum itu, peserta terlebih dahulu diberikan pemahaman tentang proses pencarian bahan literatur berupa jurnal artikel secara sistematis. Dengan demikian, Peserta akan memahami bagaimana proses yang harus dilakukan seorang peneliti dalam menemukan literatur yang tepat untuk topik penelitian yang dilakukan.

Kegiatan PkM ini bertujuan untuk memudahkan peserta dalam penulisan literature review dengan Nvivo. Untuk itu kami akan membagi materi pelatihan menjadi beberapa bagian misalnya. Tahap pertama: proses pencarian literature/referensi berupa artikel 
atau lainnya kemudian mengeksport ke reference manager seperti Mendeley atau EndNote. Tahap Kedua, Proses Instalasi paket Nvivo, dan melakukan proses integrasi antara reference manager dan Nvivo dengan melakukan proses import. Tahap ketiga adalah proses analisis yaitu proses coding, teks search, proses klasifikasi, visualisasi, peringkasan, dan penulisan tinjauan pustaka. Merujuk pada tujuan kegiatan ini, maka dapat diuraikan beberapa point-point hasil pelaksanaan dari kegiatan PkM ini:

\section{a. Peserta mampu melakukan pencarian literatur berupa artikel sesuai dengan topik penelitian yang ditekuni.}

Peserta pada kegiatan PkM ini diberikan pengetahuan tentang bagaimana proses pencarian literatur secara sistematis. Hal ini bertujuan agar literatur yang didapatkan adalah literatur yang benar-benar sesuai dengan bidang ilmu yang diteliti dan sesuai dengan topik penelitian yang sedang dilakukan. Konsep Boolean logic kami perkenalkan kepada peserta tentang manfaatnya dalam proses pencarian jurnal artikel. Konsep penggunaan "AND", "OR", dan "NOT" kami perkenalkan kepada seluruh peserta agar memahami tujuan dari penggunaan dari teknik Boolean. Hal ini dimaksudkan agar literatur jurnal yang nantinya diperoleh memang sesuai dengan topik penelitian yang dilakukan.
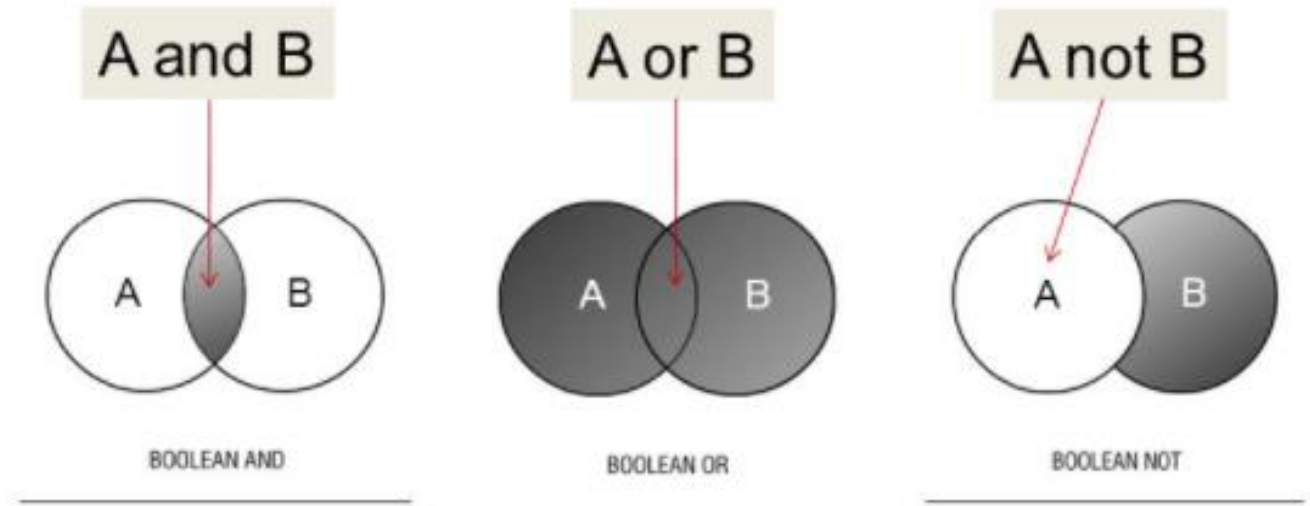

Gambar 2. Teknik Boolean yang digunakan dalam proses pencarian literatur

\section{b. Peserta mampu melakukan instalasi paket software Nvivo secara mandiri.}

Setelah peserta mampu menggunakan teknik Boolean dalam pencarian literatur jurnal, selanjutnya kami memandu peserta untuk melakukan instalasi software Nvivo pada laptop masing-masing. Hal ini penting agar peserta mampu melakukan instalasi secara mandiri software Nvivo. Selain itu, hal ini juga bertujuan untuk meminimalkan kegagalan pada saat instalasi software Nvivo pada laptop peserta. 


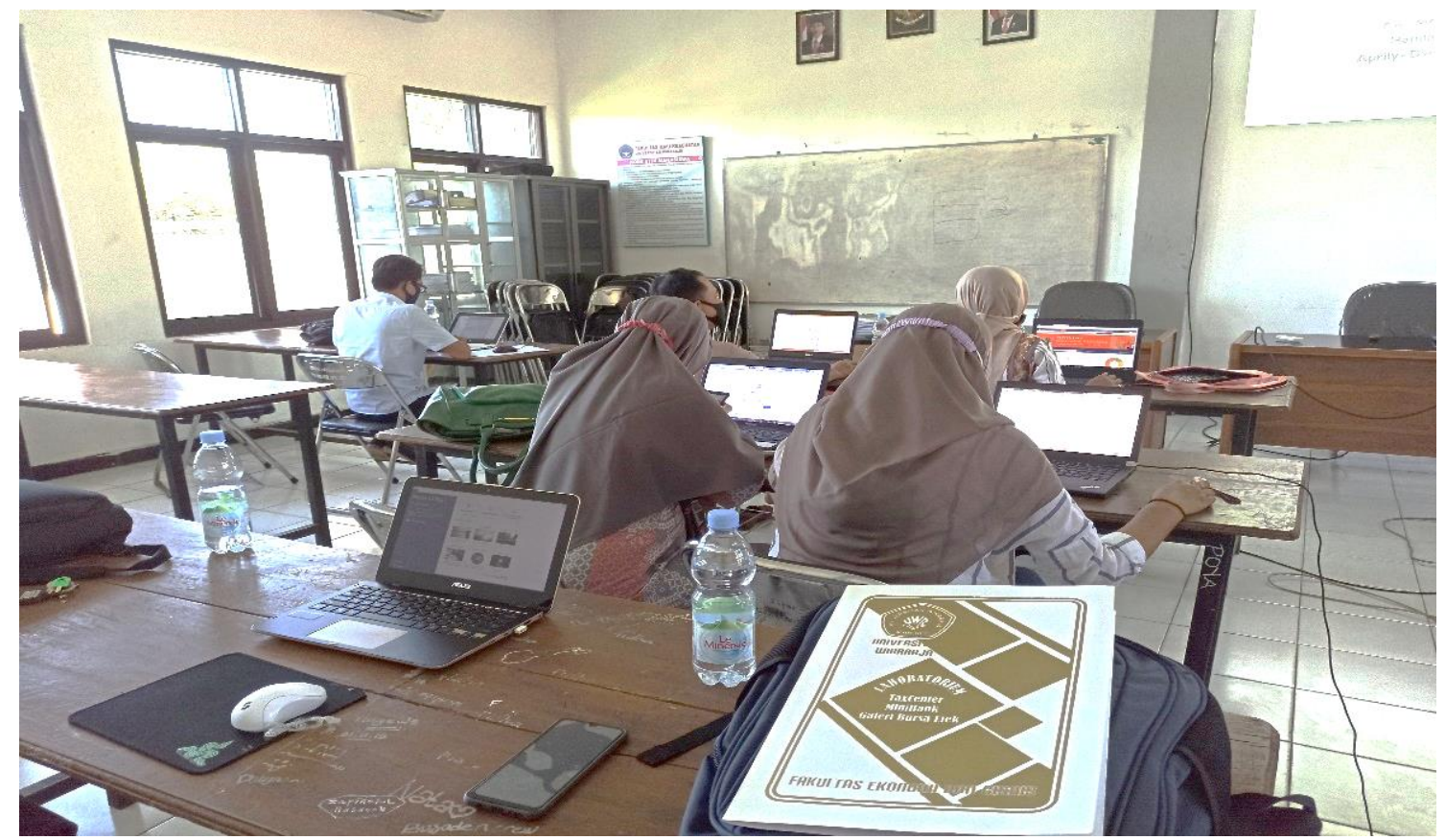

Gambar 3. Proses Instalasi Software NVivo

\section{c. Peserta mampu melakukan import data artikel jurnal kedalam software Nvivo}

Pada kegiatan kali ini, peserta kami pandu untuk untuk melakukan import data leteratur dari perangkat reference manajer (Mendeley) kepada software Nvivo. Hal ini untuk memastikan bahwa seluruh peserta mampu melalukan iport data dan memastikan bahwa tahapan import berlajan lancar dan tidak terjadi kesalahan. Pada tahapan ini seluruh peserta mampu melakukan import data literatur dari Mendeley ke NVivo.

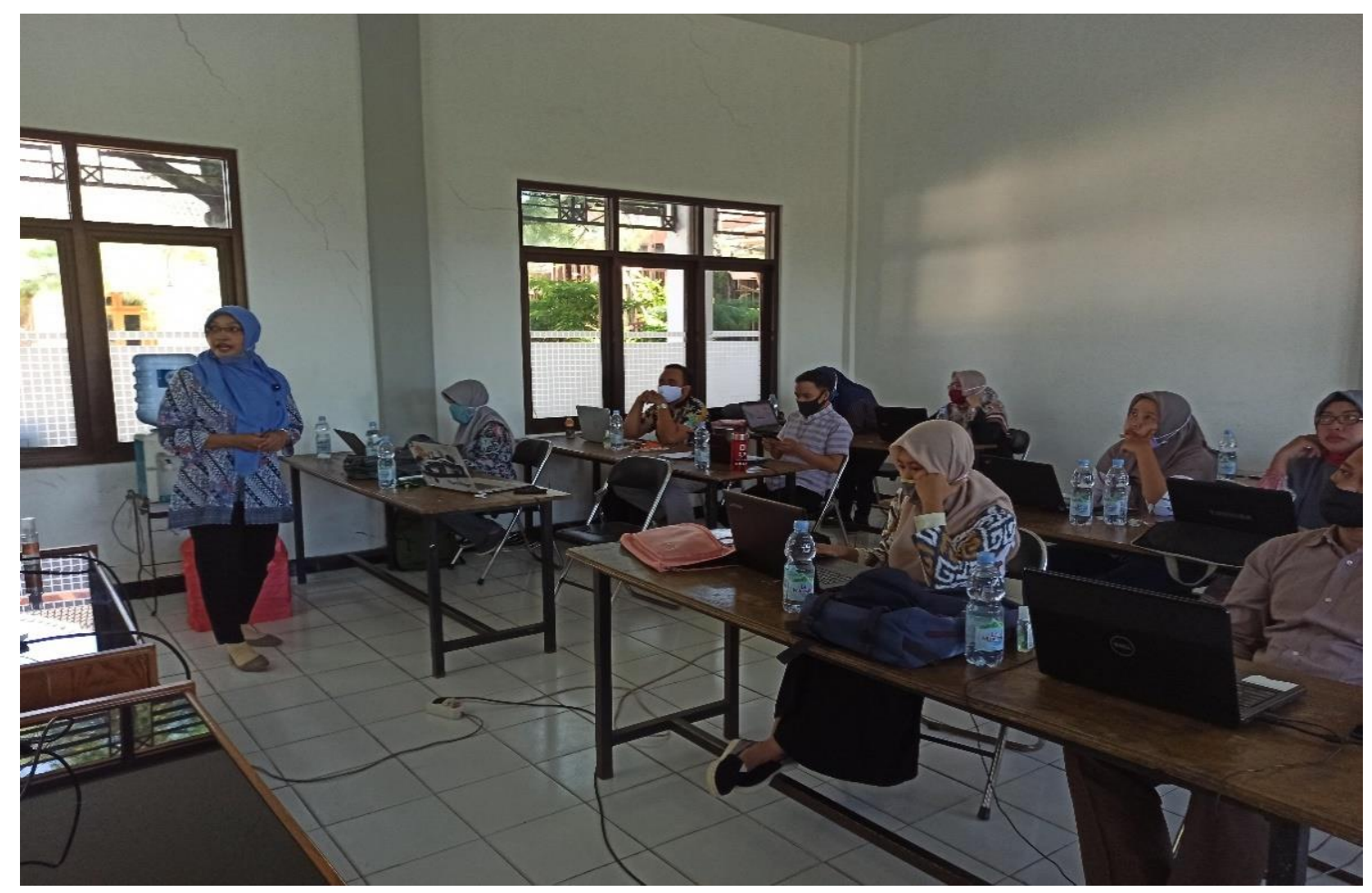

Gambar 4. Penjelasan tentang proses import dari Mendeley ke NVivo 
Vol. 2, No. 1, Februari 2021

ISSN 2721-4834

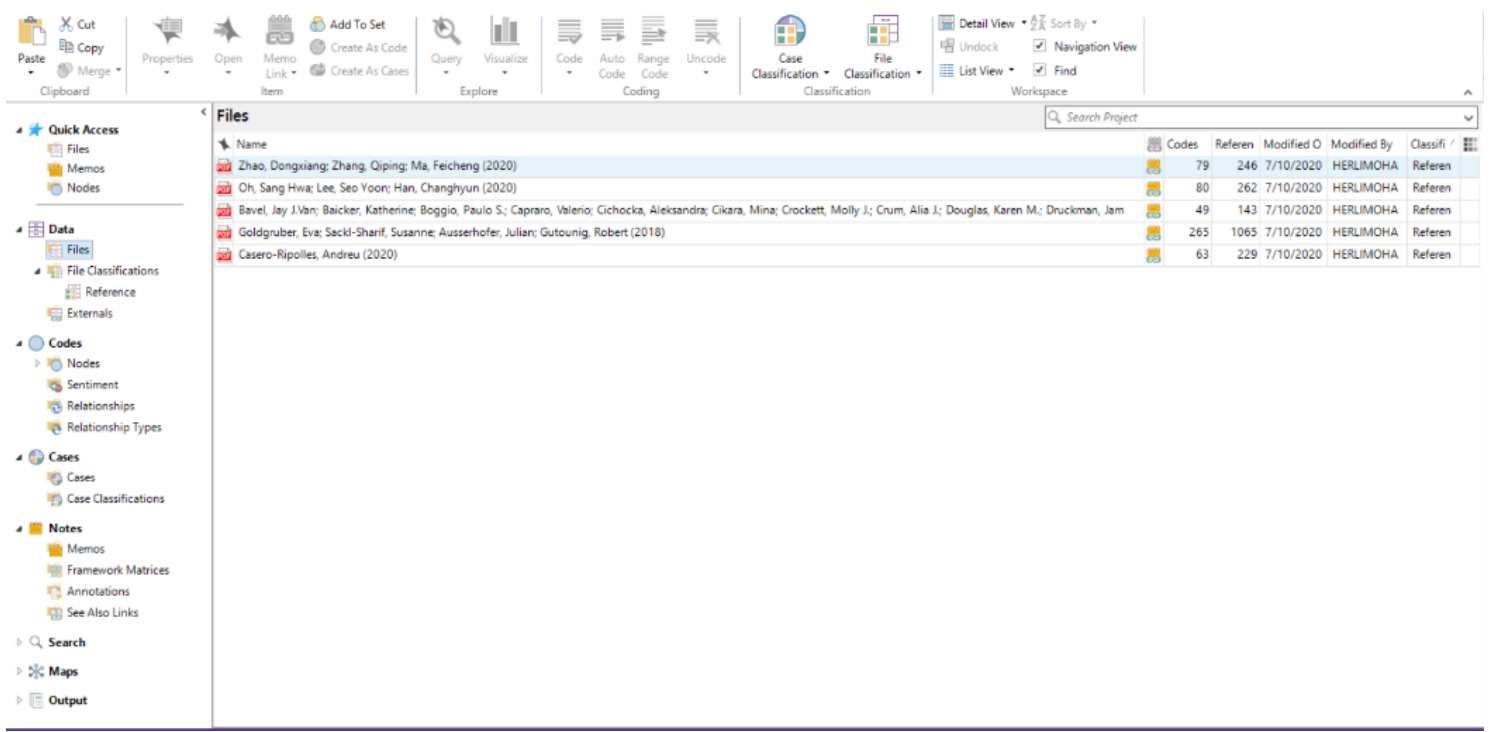

Gambar 5. Proses Import dari Reference Manajer Mendeley

\section{d. Peserta mampu memvisualisasikan dan menulis literature review dengan bantuan software Nvivo.}

Setelah data literature berhasil diimport kedalam software NVivo, selanjutnya kami memandu peserta untuk melakukan coding (auto coding maupun manual coding), text search, dan visualisasi data. Hal ini bertujuan agar peserta mampu mengidentifikasi tema pada artikel, menemukan gap penelitian, serta memungkinkan peserta untuk menentukan novelty dari penelitian yang akan dilakukan.

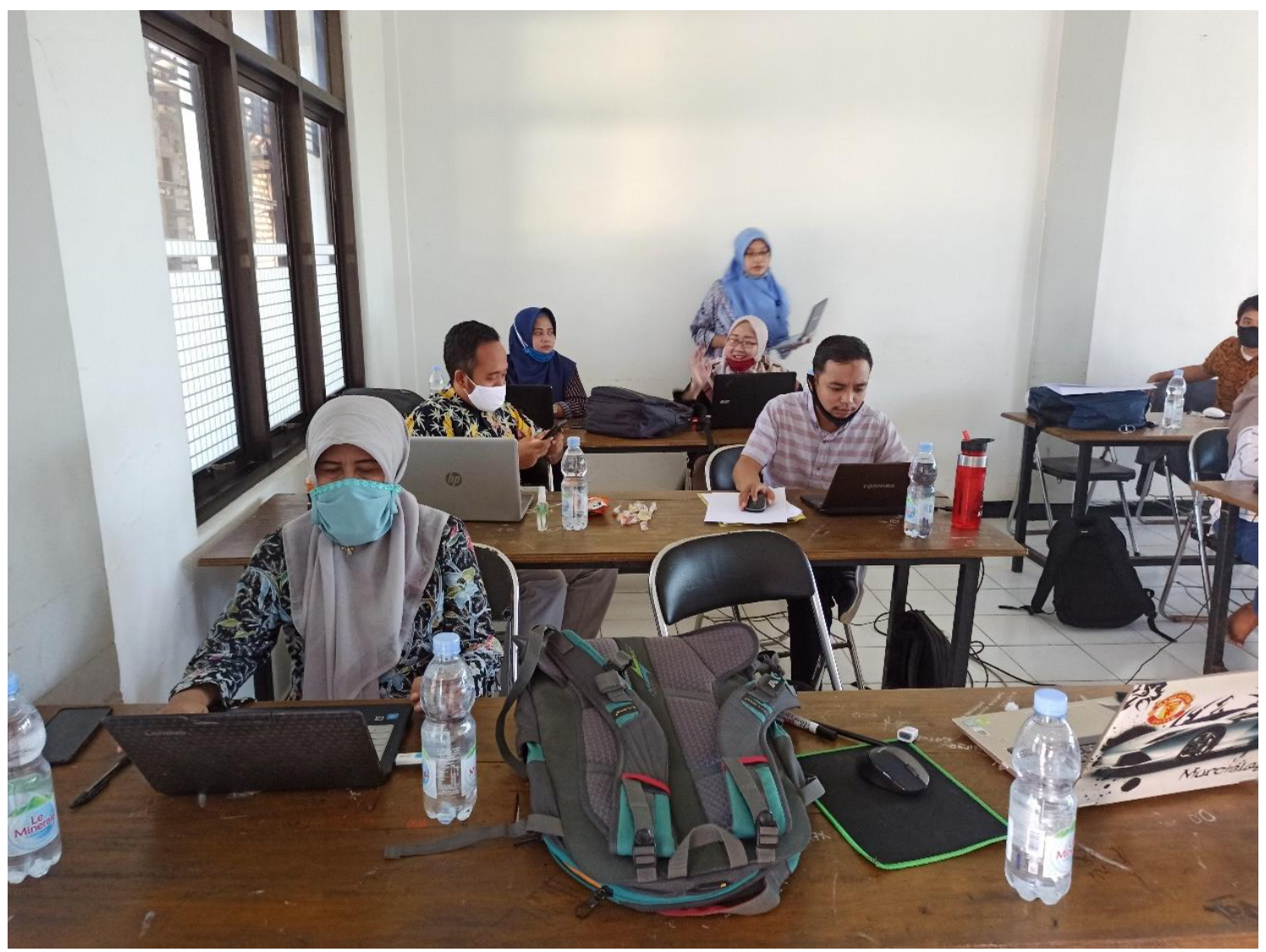

Gambar 6. Pendampingan Peserta 
Berikut kami tampilkan beberapa screenshot bagaimana proses tersebut dilakukan dalam kegiatan PkM ini.

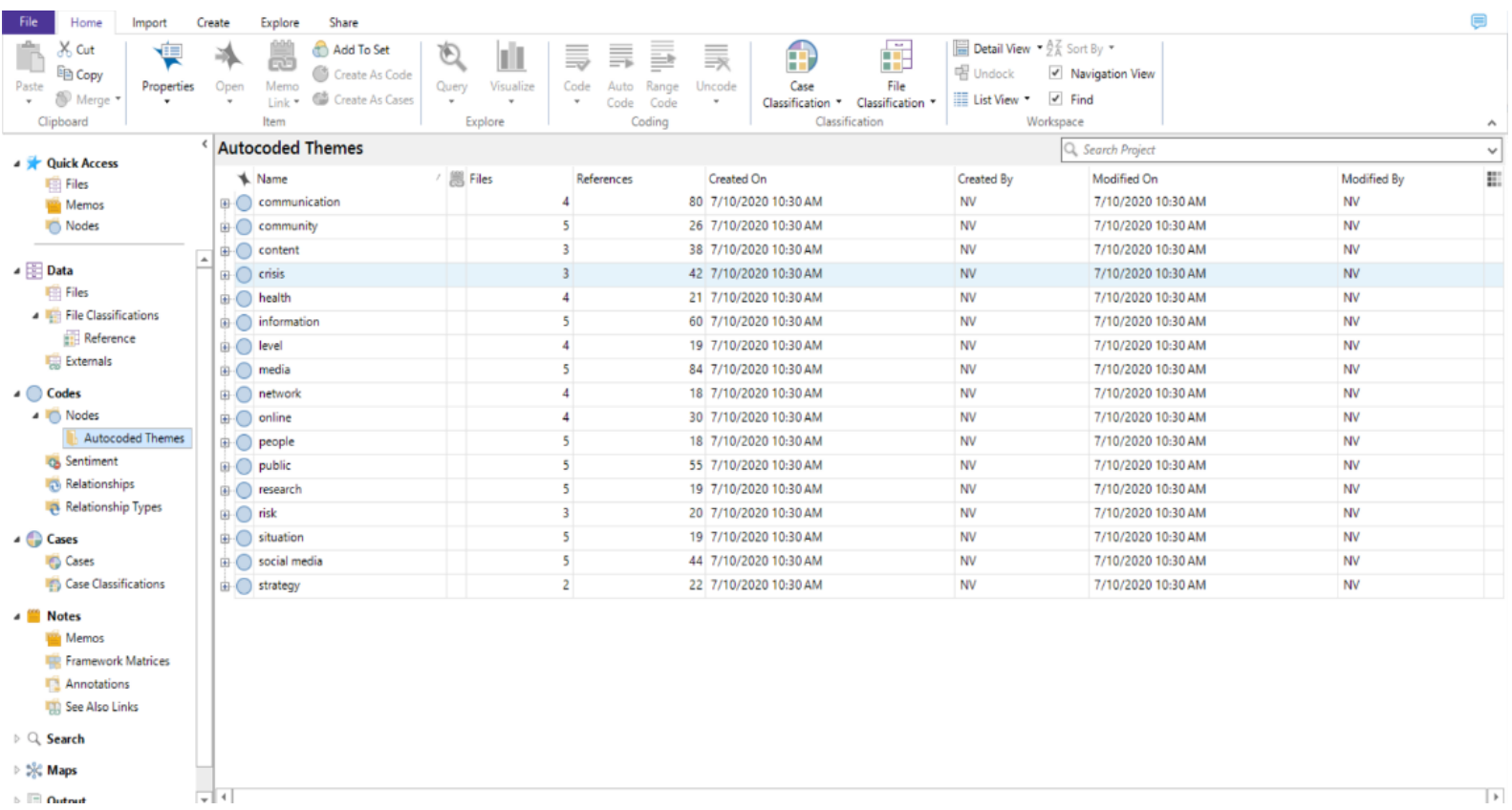

Gambar 7. Coding Artikel

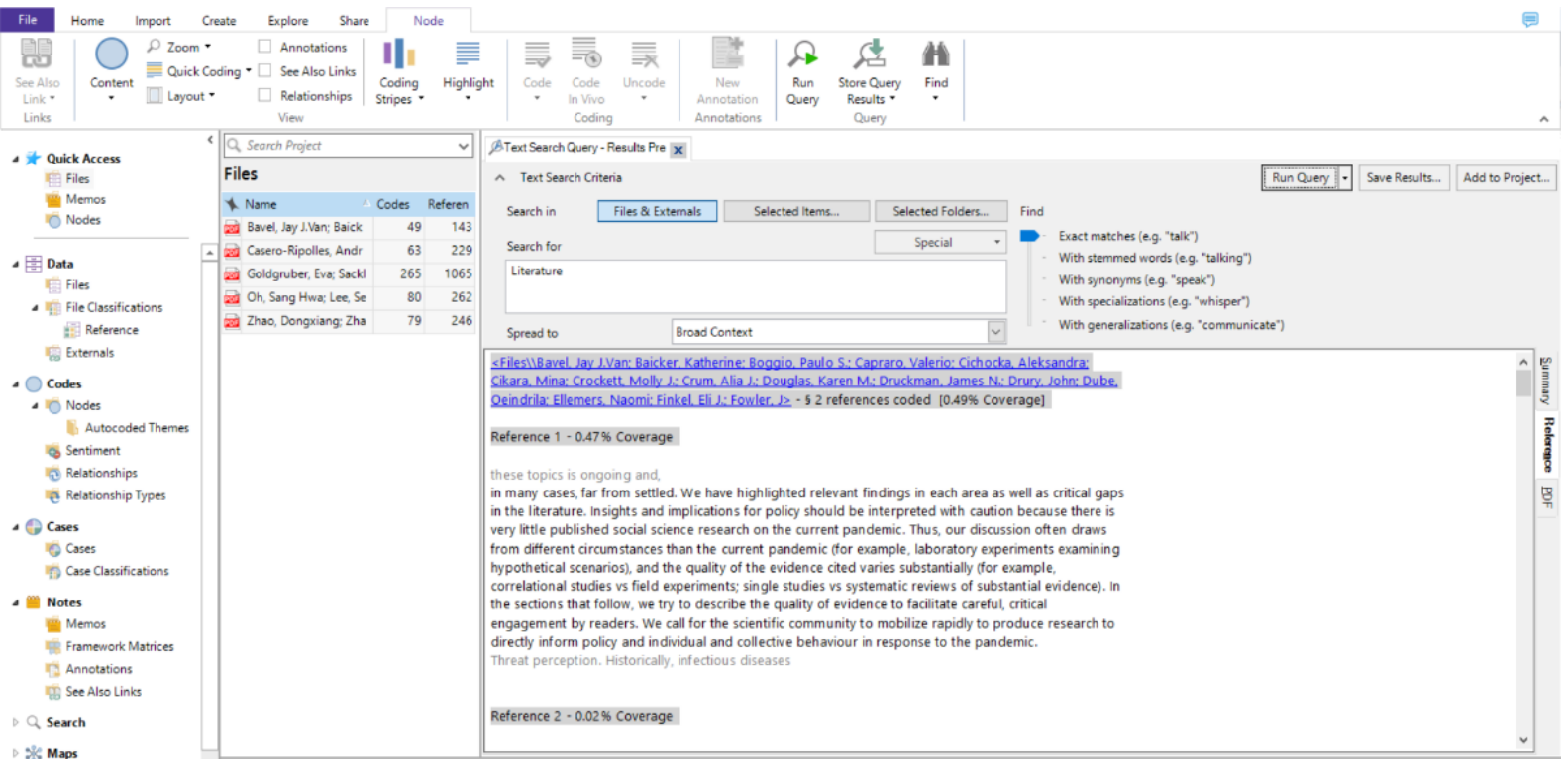

Gambar 8. Text Search 


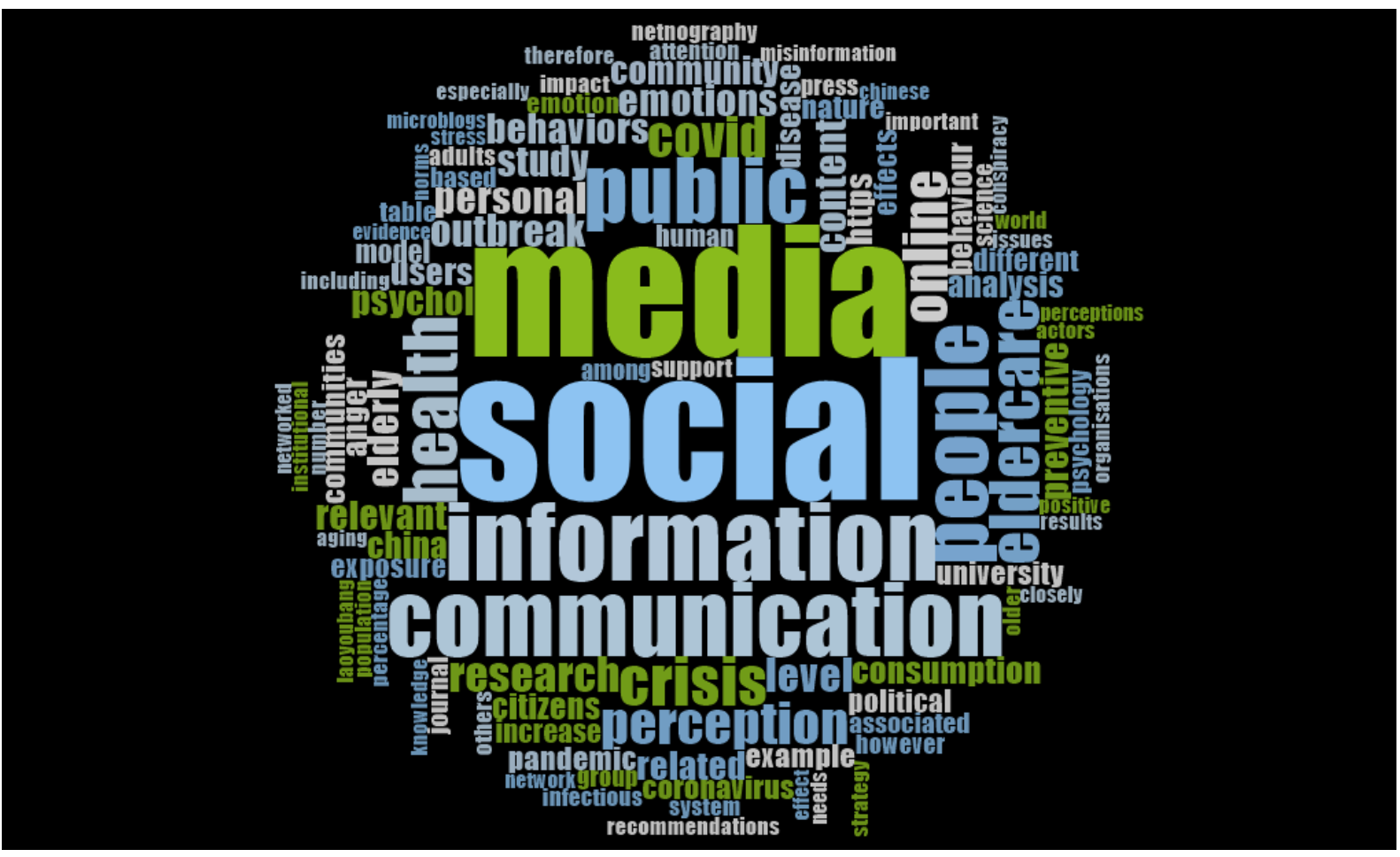

Gambar 9. Visualisasi Data berupa Word Cloud

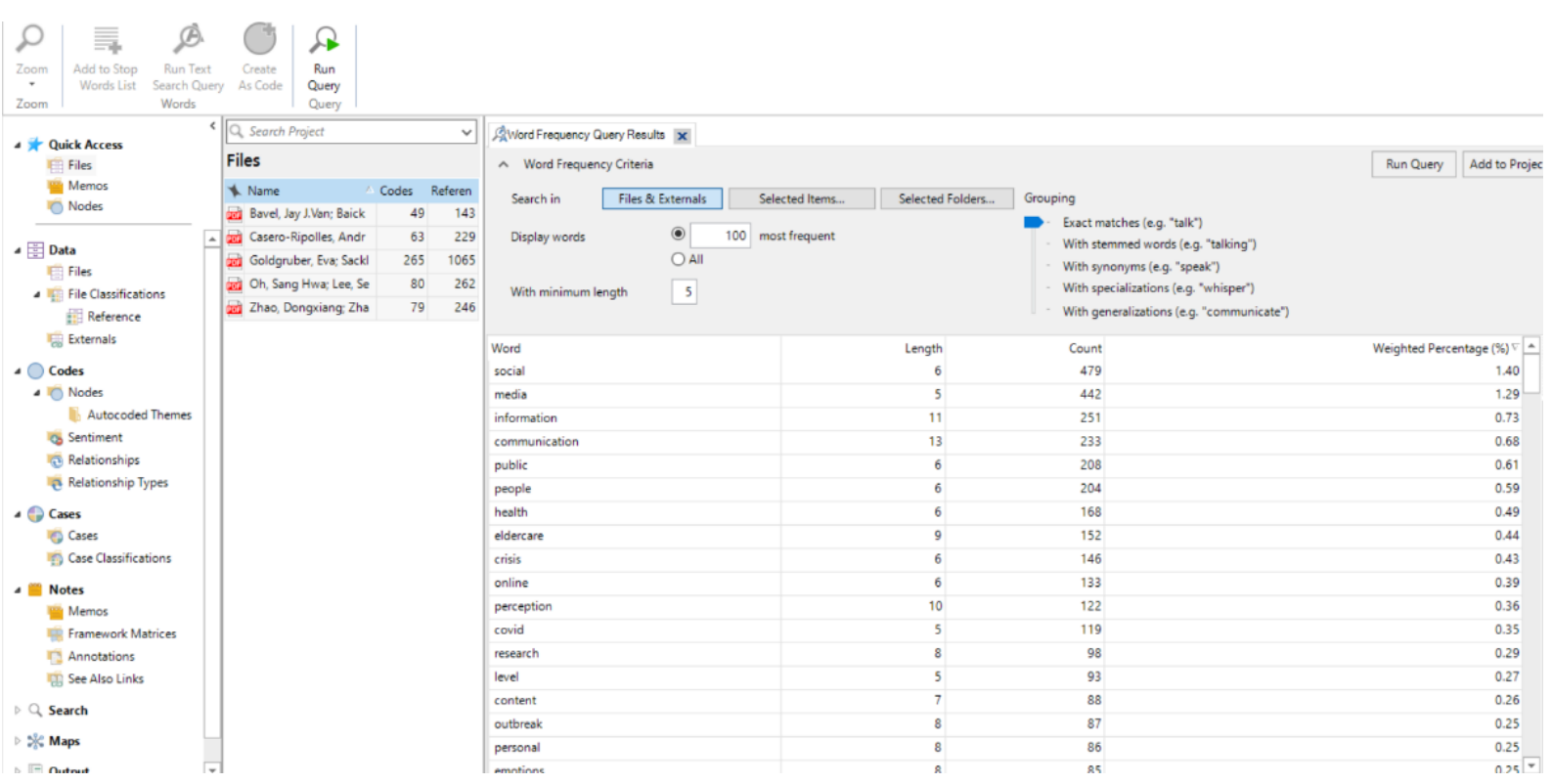

Gambar 10. Visualisasi Data

Setelah semua tahapan dilakukan, maka selanjutnya adalah melakukan evaluasi terhadap kegiatan. Berdasarkan hasil evaluasi yang dilakukan kepada peserta, mayoritas peserta telah memahami proses penyusunan literature review dengan bantuan NVivo. Peserta merasa terbantu dalam menemukan ide penelitian dan merumuskannya dalam penelitian. Hasil ini senada dengan hasil angket yang diberikan saat akhir sesi pelaksanaan kegiatan, dimana para peserta merasa puas dengan kegiatan yang dilaksanakan. 


\section{Kesimpulan}

Permasalahan umum yang dihadapi oleh peneliti dan mahasiswa yang melakukan penelitian adalah kelemahan mereka dalam menemukan literatur yang tepat untuk ide penelitian yang akan dilakukan. Selain itu permasalahan lainnya adalah kelemahan dalam menyusun literature review. Kegiatan PkM ini membantu peneliti baik dosen dan mahasiswa dalam menemukan ide penelitian, mencari literatur, dan menyusun literatur review dengan bantuan perangkat NVivo 12 Plus.

Kegiatan PkM ini memberikan pengalaman baru kepada dosen dan mahasiswa tentang proses menyusun literature review yang mudah dan sistematis. NVivo yang diguanakan dalam kegiatan PkM ini memerikan kemudahan bagi peserta dalam mencari ide penelitian, menemukan literatur yang tepat, serta memudahkan dalam penyusunan penelitian. Para peserta sangat puas dengan kegiatan ini dan merasa memperoleh pengaman baru dalam menunjang peningkatan kualitas penelitian mereka.

\section{Ucapan Terimakasih}

Terima kasih kepada Lembaga Pengabdian kepada Masyarakat (LPkM) Universitas Wiraraja yang telah mendanai kegiatan pengabdian ini. Terima kasih juga kepada segenap dosen dan mahasiswa Fakultas Ekonomi dan Bisnis Universitas Wiraraja sebagai mitra dari kegiatan PkM ini.

\section{Referensi}

Adams, R. J., Smart, P., \& Huff, A. S. (2017). Shades of Grey: Guidelines for Working with the Grey Literature in Systematic Reviews for Management and Organizational Studies. International Journal of Management Reviews, 19(4), 432-454. https://doi.org/10.1111/ijmr.12102

Edwards-Jones, A. (2014). Qualitative data analysis with NVIVO. Journal of Education for Teaching, 40(2), 193-195. https://doi.org/10.1080/02607476.2013.866724

MacDonald, J. (2014). Systematic Approaches to a Successful Literature Review. Journal of the Canadian Health Libraries Association / Journal de l'Association Des Bibliothèques de La Santé Du Canada, 34(1), 46. https://doi.org/10.5596/c13-009

Machi, L. A., \& McEvoy, B. T. (2008). The Literature Review: Six Steps to Success. Corwin Press.

Pautasso, M. (2013). Ten Simple Rules for Writing a Literature Review. PLoS Computational Biology, 9(7). https://doi.org/10.1371/journal.pcbi.1003149 